Lingua Rima: Jurnal Pendidikan Bahasa dan Sastra Indonesia

Vol. 11 No. 1 Januari 2022

http://jurnal.umt.ac.id/index.php/lgrm

\title{
LITERASI KELUARGA: STRATEGI MENUMBUHKAN KEBIASAAN TANGGUNGJAWAB MEMBACA KEPADA ANAK
}

\author{
Mulasih \\ Universitas Peradaban Bumiayu \\ mulasih@peradaban.ac.id
}

\begin{abstract}
ABSTRAK
Membaca adalah kegiatan penalaran suatu informasi yang disajikan dalam bentuk angka atau huruf merupakan salah satu bentuk implementasi dari kemampuan literasi. Kemampuan literasi sendiri dianggap menjadi salah satu komponen yang diakui menjadi tujuan pendidikan dan pengembangan setiap negara, walaupun pada kenyataannya Indonesia masih sangat tertinggal jauh. Salah satu bentuk penanganan isu ini adalah dengan menanamkan kebiasaan tanggungjawab membaca sejak dini kepada anak dengan menciptakan keluarga yang literat. Anak yang memiliki ciri khas sikap imitatif atau suka meniru, akan mudah dibentuk dengan penciptaan keluarga yang siap mencontohkan sikap literat atau banyak melakukan kegiatan terkait literasi, seperti memperbanyak interaksi dengan buku, mempunyai koleksi buku, sering membaca buku, sering memegang buku dan membolak-balik buku dan sering membacakan buku buat anak-anaknya. Dengan menggunakan metode studi literatur, penelitian ini menyajikan peran orang tua dalam menciptakan literasi keluarga, dari mulai mendeteksi kebutuhan dan gaya belajar anak, membudayakan minat baca di tengah keluarga, hingga melakukan penguatan terhadap budaya yang diciptakan.
\end{abstract}

Kata kunci: membaca, keluarga, literasi, tanggungjawab

\section{A. PENDahuluan}

Membaca (Zahro, Atika, dan Weithisi, 2019) merupakan segala kegiatan yang berhubungan dengan penalaran suatu informasi dalam sajian angka atau huruf dan berkaitan dengan kemampuan literasi. Sebagaimana Arsa (2019) mengungkapkan bahwa kemampuan literasi dapat didefinisikan sebagai kemampuan untuk menyerap informasi berbentuk ilmu pengetahuan dari teks ataupun lisan berkaitan dengan penumbuhkembangan kemampuan kognisi, yang implementasi spesifiknya bisa dalam kegiatan membaca atau menulis. Dalam proses pendidikan, kemampuan literasi disebut sebagai komponen penting dalam proses komunikasi akademik (Pratomo \& Purnaningrum, 2020), yang mana keberadaannya menentukan kualitas dari pendidikan itu sendiri. 


\section{Lingua Rima: Jurnal Pendidikan Bahasa dan Sastra Indonesia \\ Vol. 11 No. 1 Januari 2022 \\ http://jurnal.umt.ac.id/index.php/lgrm}

Itulah mengapa sudah sejak lama, pengembangan kemampuan literasi terutama dalam minat membaca menjadi fokus pendidikan. Khawarizmi (2015) menyebutkan bahwa untuk melalui abad 21 dengan kebutuhan sumber daya manusia yang tinggi, kemampuan literasi dibutuhkan agar Indonesia dapat memberikan bangsa yang memiliki daya saing tinggi karena aktif dalam melakukan penalaahan informasi yang nantinya sangat berhubungan dengan sauah menjadi kehidupan (berkompetisi). Sayangnya meski menjadi wacana lama, pada survey terbaru yang dilakukan oleh Puslitjakdibud (2019), ditemukan fakta bahwa indeks aktivitas literasi membaca atau disebut sebagai alibaca di 34 provisi Indonesia terbukti rendah. Sementara di mata dunia, berdasar data yang disajikan UNESCO, minat baca masyarakat Indonesia sangat memprihatinkan, yakni hanya $0,001 \%$, atau dalam artian hanya ada 1 orang yang memiliki minat membaca yang tinggi dari 1000 orang. Jumlah ini menyebabkan Indonesia dinobatkan sebagai negara kedua peringkat terbawah minat literasi dari 61 negera di dunia (diakses dari kominfo.go.id pada 12 Februari 2020).

Dengan fakta demikian, urgensi peningkatan membaca seharusnya menjadi terus meningkat dan diperhatikan oleh semua pihak. Menurut Irna (2019), salah satu teknik peningkatan minat baca pada masyarakat dapat dilakukan dengan melakukan pembiasan pengenalan literasi dimulai sejak anak usia dini. Karena pada rentan usia dini, anak memiliki kelekatan terkuat dengan keluarga, sehingga keluarga mengambil peran dominan dalam menentukan tingkat keberhasilan pendidikan seorang anak. Anak yang memiliki ciri khas sikap imitatif atau suka meniru, akan mudah dibentuk dengan penciptaan keluarga yang siap mencontohkan sikap literat atau banyak melakukan kegiatan terkait literasi, seperti memperbanyak interaksi dengan buku, mempunyai koleksi buku, sering membaca buku, sering memegang buku dan membolakbalik buku dan sering membacakan buku buat anak-anaknya.

Selain Irna, penelitian sebelumnya yang dilakukan oleh Inten (2017) juga membuktikan bahwa peran keluarga menjadi sangat intens dalam mempercepat apresisi minat baca yang tinggi apabila penciptaan keluarga yang literat dengan prinsip pemberian perhatian, kasih sayang, keteladanan, dorongan dan keterlibatan langsung orang tua dalam kegiatan literasi. Para orang tua seharusnya mampu membimbing anak-anaknya sejak dini untuk gemar membaca (Hudhana dan Ariyana, 2018). Melalui hal tersebut, peneliti menekankan penelitian kali ini untuk mengembangkan strategi bagi keluarga dalam penciptaan keluarga yang literat dan siap untuk menumbuhkan kebiasaan tanggungjawab membaca pada anak terutama yang berada di usia dini. 


\section{Lingua Rima: Jurnal Pendidikan Bahasa dan Sastra Indonesia \\ Vol. 11 No. 1 Januari 2022 \\ http://jurnal.umt.ac.id/index.php/lgrm}

\section{B. METODELOGI PENELITIAN}

Metode penelitian yang digunakan dalam artikel ini adalah studi literatur. Zahro, Atika \& Wethisi (2019) menyebutkan dengan desain literatur, peneliti dapat menyajikan data penelitian dengan menggunakan sumber rujukan primer seperti jurnal, data hasilan penelitian dan laporan penelitian, dan menggunakan sumber sekunder seperti buku, peraturan dasar hukum dan sebagainya. Rujukan yang dipilih kemudian dijadikan landasan pemikiran yang akan melalui langkah sintesis gagasan/ide solusi secara sistematis untuk menyimpulkan setiap fakta yang didapatkan dalam rujukan. Hasil sintesis inilah yang akan disajikan dalam artikel untuk mencapai tujuan dalam memberikan solusi yang dapat ditampilkan pada khalayak.

\section{HASIL PENELITIAN DAN PEMBAHASAN}

Dalam rangka, menciptakan lingkungan keluarga yang literat atau memiliki napas literasi di dalamnya, sehingga penciptaan generasi minat baca menjadi lebih dapat kondusif, penulis menyajikan strategi yang didapatkan dengan deduksi penelitian terdahulu.

\section{Deteksi Dini Kebutuhan dan Gaya belajar Anak}

Arsa (2019) mengungkapkan bahwasannya kegiatan literasi memerlukan serangkaian kemampuan yang kompleks seperti kemampuan kognitif, pengetahuan bahasa tulisan dan lisan, pengetahuan mengenai genre, dan pengetahuan mengenai kultural. Sebagaimana diangkap membutuhkan kemampuan yang kompleks, ada satu teori yang dapat menjelaskan bahwa manusia memiliki potensi suatu kecerdasan majemuk atau lebih dikenal sebagai multiple intelligence yang dikemukakan oleh Howard Gadner. Manusia dianggap memiliki 9 potensi kecerdasan, seperti:

1. Kecerdasan linguistik, atau kemampuan seseorang untuk berpikir dengan menggunakan kata dan bahasa untuk mengekspresikan arti kompleks.

2. Kecerdasan matematis/logis, atau kemampuan seseorang dalam hal hitungan atau kuantifikasi.

3. Kecerdasan spasial, atau orang yang mempunyai kapasitas dalam berpikir secara tiga dimensi.

4. Kecerdasan kinestetik, atau kemampuan seseorang untuk memanipulasi objek dan melakukan aktivitas fisik. 


\section{Lingua Rima: Jurnal Pendidikan Bahasa dan Sastra Indonesia \\ Vol. 11 No. 1 Januari 2022 \\ http://jurnal.umt.ac.id/index.php/lgrm}

5. Kecerdasan musikal, kecerdasan yang yang berkaitan dengan rasa sensitif terhadap nada, irama musik, melodi atau hal lain yang berkaitan dengan musik.

6. Kecerdasan interpersonal, yaitu kapasitas yang dimiliki untuk dapat memahami dan melakukan interaksi efektif dengan orang lain.

7. Kecerdasan intrapersonal, atau kapasitas seseorang untuk membangun persepsi yang akurat mengenai dirinya dan dapat mengarahkan orang lain.

8. Kecerdasan Naturalis, yaitu bentuk kecerdasan untuk mengkategorisasikan spesies (flaura dan fauna) di lingkungannya.

9. Kecerdasan eksistensial, atau kemampuan menjawab persoalan-persoalan atau memiliki kecerdasan spiritual (dalam Abidin, 2017)

Meskipun kemampuan literasi seperti hanya implementasi dari kemampuan atau kecerdasan linguistik karena sama-sama berhubungan dalam mengakses informasi dengan kata atau bahasa, pada kenyataannya, literasi lebih luas dari hal itu. Pemahaman mengenai potensi majemuk yang dimiliki oleh anak, justru akan membantu proses pembentukan minat anak dalam membaca sesuai dengan potensi yang dimiliknya. Sebagaimana Rapih (2016) memaknai pendidikan literasi pada untuk mengajarkan anak mengenai literasi keuangan atau kemampuan membaca, menganalisa dan mengelola keuangan secara bijak dan mengontrol pengeluaran keuangan dengan membedakan hal-hal yang berkaitan dengan kebutuhan atau hanya keinginan. Pada konteks ini, literasi berkaitan dengan kecerdasan matematika/logis.

Selain itu, Suhaimi (2017) juga menggunakan potensi kecerdasan kinestetik untuk meningkatkan kemampuan literasi pada anak. Misalnya anak yang suka bergerak atau atraktif dapat dimanfaatkan untuk kemampuan verbal dengan membaca serta menebak makna atau nama dari sebuah gerakan yang ditimbulkan oleh respek atau manipulasi gerak anak. Contoh konkret menyandingkan kemampuan kinestetik dan kemampuan linguistik anak dapat dapat sebagai berikut, orang tua menuliskan kosa kata "tentara", kemudian meminta anak untuk membaca dan mempraktikan gerakan yang dapat merepresentasikan tentara, atau dengan cara sebaliknya, yaitu orang tua mempraktikkan gerakan yang merepresentasikan gerakan tentara lalu meminta anak untuk menebak, menuliskan, dan membaca jawaban mereka.

Sementara Zahro, Atika dan Westhisi (2019) menggunakan literasi sains untuk mengembangkan kegiatan literasi yang berkaitan dengan pemecahan masalah yang berkaitan dengan kemampuan ilmiah anak untuk memahami anggota tubuh dan fungsi gerak, mengetahui 


\section{Lingua Rima: Jurnal Pendidikan Bahasa dan Sastra Indonesia \\ Vol. 11 No. 1 Januari 2022 \\ http://jurnal.umt.ac.id/index.php/lgrm}

cara hidup sehat, pemecahan masalah sehari-hari dan kreativitas, mengenal benda sekirtar, mengenal lingkungan sekitar, hingga mengenal teknologi dasar, yang tentunya mewadahi kecerdasan majemuk.

Tiga contoh di atas dapat menjadi bukti, bahwa pemahaman potensi yang paling dominan dari dini anak juga dapat menjadi pendeteksi kebutuhan dan model seperti apa yang dibutuhkan untuk mencapai minat literasi sesuai dengan passion mereka. Pada perkembangannya, literasi juga diperluas konsepnya menjadi multilerasi (Anggraeni, Fauziyah. \& Fahyuni, 2019). Selain berkaitan dengan kecerdasan, orang tua juga perlu memahami bagaimana cara efektif anak belajar, atau gaya belajar yang paling didalami anak. Susilowati (2018) mengungkapkan bahwa ada banyak model gaya belajar salah satunya gaya belajar Dave Mayer, yang menjadikan 4 bentuk gaya belajar, yaitu:

1. Gaya Somatis, atau anak yang belajar dengan indra peraba, kinestetis, praktis-melibatkan fisik dan menggunakan serta menggerakkan tubuh sewaktu belajar. Sehingga penanaman minat literasi, dapat dilakukan dengan mengadaptasi kegiatan fisik. Misalnya membacakan kisah dongeng sembari melakukan pertujukkan drama untuk mempraktikkan kisah yang diceritakan.

2. Gaya Auditory, atau cara belajar dengan mendengarkan secara aktif. Implementasinya dapat dengan mendongengi anak sebelum tidur.

3. Gaya Visual, atau cara belajar dengan cara melihat. Sehingga, buku bergambar mungkin akan lebih menarik perhatian anak.

4. Gaya intelektual, atau dengan merenungkan masalah dan menggunakan pengalaman sebagai pengetahuan. Sehingga metode mendiskusikan suatu bahan bacaan mungkin menjadi metode yang tepat.

Setelah mengerti jenis kecerdasan anak, sehingga memungkinkan orang tua mengerti konteks bacaan seperti apa yang akan diberikan kepada anak, lalu bagaimana menyampaikannya kepada anak dengan pengenalan gaya belajar, hal lain yang dapat dipelajari adalah batasan atau goal mengenalkan budaya literasi pada anak. Pengenalan awal budaya literasi terutama membaca dapat dibagi dalam beberapa tahapan, seperti:

1. Tahap pertama dengan tujuan menimbulkan kesadaran terhadap tulisan, yang ditandai dengan kegemaran anak melihat-lihat dan membolak-balikkan buku serta menyadari bahwa buku adalah sesuatu yang penting. 


\section{Lingua Rima: Jurnal Pendidikan Bahasa dan Sastra Indonesia \\ Vol. 11 No. 1 Januari 2022 \\ http://jurnal.umt.ac.id/index.php/lgrm}

2. Tahap kedua dengan tujuan anak mulai membaca gambar, biasanya anak mulai berpurapura membaca buku dengan mencocokkan gambarnya meskipun tidak sesuai dengan tulisan, tetapi anak mulai menyadari bahwa buku memiliki karakteristik seperti judul, halaman, kata dan kalimat serta tanda baca.

3. Tahap ketiga, dengan tujuan anak mulai masuk kedalam tahapan pengenalaann bacaan atau mulai dapat menggunakan tiga sistem bahasa, seperti fonem (bunyi huruf), semantik (arti kata) dan sintaksis (aturan kata dan kalimat).

4. Tahap keempat, anak mulai dapat membaca lancar, dan sudah dapat membaca berbagai jenis buku berbeda serta bahan yang langsung berhubungan dengan kehidupan mereka sehari-sehari atau sesuai dengan kecerdasan yang paling dominan. (Jamaris, dalam Husnani, 2018)

Pengenalan tujuan dari setiap tahapan ini juga dapat membantu orang tua untuk memahami bahwa anak memiliki proses tersendiri untuk memahami suatu konsep baru yang perlu waktu dan tahapan yang tidak instan.

\section{Pembudayaan Aktivitas Membaca}

Zati (2018) mengungkapkan bahwa untuk meningkatkan minat baca anak, dapat dilakukan dengan cara-cara sederhana dalam kegiatan sehari-hari, seperti berbelanja, atau kegiatan lain yang menyita perhatian anak. Misalnya meminta anak untuk membuat catatan barang belanjaan yang akan mereka beli di supermarket atau menghitung jumlah barang belanjaan yang mereka beli. Maka, orangtua lebih baik mengapresiasikan pembudayaan membaca bagi anaknya, sehingga anak akan merasa lebih dihargai dan bersemangat (Mulasih, dan Hudhana, 2020). Dari penelitian Zati, dapat disimpulan bahwa untuk membuat anak minat, maka suatu konsep harus dibudayakan atau dibuat menjadi kebiasaan dimana si anak aktif di dalamnya. Irna (2019) menjelaskan ada beberapa kegiatan yang dapat dilakukan orang tua untuk membudayakan perilaku membaca:

1. Orang Tua Membacakan Buku. Sebagaimana pepatah "Like mother like daughter, like father like son”. Orang tua yang membiasakan memperlihatkan interaksi dengan buku sekaligus membacakannya akan membuat anak menjadikan itu sebagai role model dan mulai penasaran serta memunculkan rasa ingin mengikuti perilaku yang dicontohkan tersebut. 


\section{Lingua Rima: Jurnal Pendidikan Bahasa dan Sastra Indonesia \\ Vol. 11 No. 1 Januari 2022 \\ http://jurnal.umt.ac.id/index.php/lgrm}

2. Pojok baca. Anak usia dini memiliki sensitivitas tinggi terhadap rangsangan, sehingga lingkungan yang menyuplai kebutuhan konsep yang ingin kontruksi, akan membuat anak terstimulasi lebih tinggi. Misalnya orang tua menyediakan pojok baca yang ditata dengan hiasan yang indah dan menarik serta ditambah gambar dan tulisan yang mencolok, dengan lokasi buku yang mudah dijangkau anak dan nyaman akan menimbulkan ktertarikan mereka terhadap aktivitas membaca buku, baik dilakukan sendiri ataupun bersama dengan orang lain seperti aktivitas pertama. Pembuatan tempat khusus juga dapat menimbulkan kesan mendalam.

3. Mengunjungi Perpustakaan/ toko buku bersama. Anak-anak sangat menyukai kegiatan berjalan-jalan atau Field trip, mengemas kegiatan literasi dengan mengunjungi sumber belajar seperti perpustakaan atau toko buku akan meningkatkan kebermaknaan menumbuhkan minat belajar.

4. Home Visit. Kegiatan kunjungan rumah, dengan mendatangkan orang yang dapat mengevaluasi kegiatan literasi, atau orang yang menarik perhatian anak.

Semakin dekat dan natural kegiatan literasi pada kehidupan anak, maka akan semakin mudah pembudayaan kegiatan dilakukan.

\section{Reinforcement Budaya Membaca}

Metode pemberian reinforcement (penguatan) dalam suatu proses pembelajaran dengan memberikan reward untuk meningkatkan kecepatan respon adalah konsep yang dicanangkan oleh tokoh Behavioristik, Skinner. (Walgito, 2005:189). Pada konteks penelitian ini, pemberian reinsforcement berperan sebagai katalis untuk mewujudkan tanggungjawab anak dalam kegiatan membaca yang dibiasakan oleh keluarga.

Masruroh \& Kumala Dewi (2020) mengungkapkan bahwa anak usia dini termotivasi untuk melakukan sesuatu untuk mendapatkan rasa kagum, sehingga orang tua perlu menghindari penggunaan hukuman/cara kekerasan untuk mendisiplinkan anak, melainkan dengan pendekatan yang membuat anak merasa senang dan mengerti apa yang diharapkan orang tua. Reinforcement adalah salah satu cara yang dapat digunakan. Sebagaimana prinsip reinforcement adalah membagikan kehangatan, antusiasme, kebermaknaan dan menghindari respon negatif. Komponen dalam penerapan reinforcerment dapat berupa hal-hal berikut:

1. Penguatan verbal, atau reinforcement yang diberikan dalam bentuk kata pujian ketika anak berhasil memenuhi target membaca 


\section{Lingua Rima: Jurnal Pendidikan Bahasa dan Sastra Indonesia \\ Vol. 11 No. 1 Januari 2022 \\ http://jurnal.umt.ac.id/index.php/lgrm}

2. Penguatan gestural, menunjukkan gesture menyenangkan ketika anak menunjukkan minat baca

3. Pendekatan, penguatan yang dilakukan secara emosional

4. Sentuhan, memberikan sentuhan fisik misalnya mengelus kepala

5. Pemberian kegiatan yang menyenangkan bagi anak setelah berhasil menjalankan kegiatan literatur.

6. Simbol atau hadiah, dengan memberikan hadiah yang diinginkan anak ketika berhasil menjalankan kegiatan membaca.

Pemberian reinforcement ini dibagi menjadi dua, yaitu reinforcement positif dan reinforcement negatif.

1. Dalam penguat positif, frekuensi respon meningkat karena diikuti dengan stimulus yang mendukung (rewarding) (Zaini, 2014), sebagai contoh komentar orang tua kepada anak seperti memuji dan memberikan afeksi yang menunjukkan kebanggaan karena anak berhasil menunjukkan target membaca yang meningkat.

2. Sementara dalam penguat negatif, frekuensi respon meningkat karena diikuti dengan penghilangan stimulus yang merugikan (tidak menyenangkan) (Zaini, 2014), sebagai contoh anak tidak akan diberikan kewajiban membaca buku di akhir pekan jika berhasil membaca 1 buku penuh.

Pemberian reinforcement ini ditujukan agar anak mengingat bahwa kegiatan literasi seperti membaca adalah sesuatu yang menyenangkan dan dapat menjadi pencapaian yang perlu diulang, sehingga pembudayaan minat baca pada anak terus kuat dan mendalam menjadi suatu bentuk tanggungjawab yang tidak menekan karena didasarkan pada unsur kesenangan.

\section{SIMPULAN DAN SARAN}

Untuk membangun keluarga yang literat dan sarat akan sikap dan sifat literasi, perlu pondasi yang ditanamkan sejak anak usia dini, dimana orang tua masih berperan sebagai significant other. Orang tua mengambil peran untuk mengidentifikasi kebutuhan anak, kemudian menentukan model pembudayaan literasi di dalam keluarga, dan melakukan penguatan akan budaya tersebut agar benar menjadi nilai yang diyakini oleh si anak dengan memastikan bahwa budaya membaca dianggap sebagai suatu hal yang positif.

\section{E. DAFTAR PUSTAKA}




\section{Lingua Rima: Jurnal Pendidikan Bahasa dan Sastra Indonesia \\ Vol. 11 No. 1 Januari 2022 \\ http://jurnal.umt.ac.id/index.php/lgrm}

Abidin, Z. (2017). Pengembangan Kecerdasan Majemuk (Multiple Intelligences) di Madrasah. Elementary: Jurnal Ilmiah Pendidikan Dasar, 3(2), 120-131.

Arsa, D., Atmazaki, A., \& Juita, N. (2019). Literasi Awal pada Anak Usia Dini Suku Anak Dalam Dharmasraya. Jurnal Obsesi: Jurnal Pendidikan Anak Usia Dini, 3(1), 127-136.

Hudhana, W. D. dan Ariyana. 2018. Menanamkan Budaya Literasi pada Anak Usia Dini Melalui Dongeng. Jurnal Lingua Rima. 7 (1), 80-85

Husnaini, N. (2018). Identifikasi Pola Pengenalan Literasi pada Anak Usia Dini di Kota Mataram. Jurnal Pendidikan Anak, 7(1), 30-39.

Inten, D. N. (2017). Peran Keluarga Dalam Menanamkan Literasi Dini pada Anak. Golden Age: Jurnal Pendidikan Anak Usia Dini, 1(1).

Irna, I. (2019). Menumbuhkan Minat Baca Anak Usia Dini Melalui Implementasi Literasi Keluarga. Fascho, 9(1), 15-34.

Kharizmi, M. (2015). Kesulitan Siswa Sekolah Dasar Dalam Meningkatkan Kemampuan Literasi. Jurnal Pendidikan Dasar (JUPENDAS), 2(2).

Masruroh, S., \& Dewi, N. F. K. (2020). Penerapan Reinforcement dalam Mendisiplinkan Anak Usia 5-6 Tahun di TK Islam Kinasih Kecamatan Pinang Tangerang. Ceria: Jurnal Program Studi Pendidikan Anak Usia Dini, 11(2), 55-66.

Mulasih, dan Hudhana, W. D. (2020). Urgensi Budaya Literasi dan Upaya Menumbuhkan Minat Baca. Jurnal Lingua Rima. 9 (2), 19-23.

Pratomo, H. T. A., \& Purnaningrum, W. D. (2020). Deteksi Dini dan Penguatan Literasi Siswa Sekolah Dasar. Jurnal Empathy Pengabdian Kepada Masyarakat, 1(2), 137-145.

Suhaimi, I. (2017). Memberdayakan Kecerdasan Kinestetik Anak Untuk Budaya Literasi Bahasa. KREDO: Jurnal Ilmiah Bahasa dan Sastra, 1(1), 72-90.

Susilowati, R. (2018). Pemahaman Gaya Belajar pada Anak Usia Dini. ThufuLA: Jurnal Inovasi Pendidikan Guru Raudhatul Athfal, 1(1), 89-100.

Walgito, B. (2005). Pengantar Psikologi Umum. Yogyakarta: Andi Offset.

Zahro, I. F., Atika, A. R., \& Westhisi, S. M. (2019). Strategi Pembelajaran Literasi Sains Untuk Anak Usia Dini. Jurnal Ilmiah Potensia, 4(2), 121-130.

Zaini, R. (2014). Studi Atas Pemikiran BF Skinner Tentang Belajar. TERAMPIL: jurnal pendidikan dan pembelajaran dasar, 1(1), 118-129. 


\section{Lingua Rima: Jurnal Pendidikan Bahasa dan Sastra Indonesia \\ Vol. 11 No. 1 Januari 2022 \\ http://jurnal.umt.ac.id/index.php/lgrm}

Zati, V. D. A. (2018). Upaya Untuk Meningkatkan Minat Literasi Anak Usia Dini. Jurnal Bunga Rampai usia Emas, 4(1), 18-21. 